\title{
Effect of Liquid Flavor Supplementation of the Diet on Dairy Cows in the Transition Period*
}

\author{
M. A. Shah, † E. J. Friedman, A. O. Bahaa, and M. R. Murphy \\ Department of Animal Sciences, \\ University of Illinois, Urbana 61801
}

\begin{abstract}
A 9-wk trial was conducted to study the performance of 24 Holstein cows during the transition period ( $3 \mathrm{wk}$ prepartum to 6 wk postpartum). Cows were assigned to either a control or liquid-flavored $(0.52 \mathrm{~mL} / \mathrm{kg}$ of feed $)$ total mixed ration in a randomized complete block design. The diets contained corn silage, alfalfa haylage, cottonseed, and a grain mix based on ground corn and soybean meal. Cows were fed to ensure $10 \%$ orts, and the diet provided (on a dry matter basis) $13 \%$ crude protein, $32 \%$ acid detergent fiber, $44 \%$ neutral detergent fiber, and $1.54 \mathrm{Mcal} / \mathrm{kg}$ of $\mathrm{NE}_{\mathrm{L}}$ prepartum and $17.5 \%$ crude protein, $30 \%$ acid detergent fiber, $40 \%$ neutral detergent fiber, and $1.57 \mathrm{Mcal} / \mathrm{kg}$ of $\mathrm{NE}_{\mathrm{L}}$ postpartum. An additional $2.3 \mathrm{~kg}$ of alfalfa hay was fed during the first $5 \mathrm{~d}$ postpartum. Weekly means of dry matter intake (DMI), milk yield, milk protein, milk fat, SNF, somatic cell counts, and body weight (BW) were analyzed using a repeated measures procedure. There was no effect of treatment on these variables, and least squares means were 16.9 and $15.7 \mathrm{~kg} / \mathrm{d}$ for DMI, 38 and $35.3 \mathrm{~kg} / \mathrm{d}$ for milk yield, 3.10 and $3.11 \%$ for milk protein, 3.69 and $3.74 \%$ for milk fat, 8.37 and $8.16 \%$ for SNF, $1.99 \times 10^{5}$ and $4.33 \times 10^{5}$ for somatic cell count, and 631 and $651 \mathrm{~kg}$ for BW for cows fed control and flavored diets, respectively. Individual cow daily DMI data were fitted to an exponential model describing preand postpartum feed consumption [DMI $=\mathrm{a}-\mathrm{b} \times$ $\mathrm{e}^{(-\mathrm{c} \times \mathrm{t})}$, where DMI was measured in $\mathrm{kg}, \mathrm{a}=$ asymptotic DMI, $b=$ potential fractional increase in DMI, $c=$ fractional rate of increase in DMI, and $t=$ days prior to calving or days in milk]. Fractional rates of increase in DMI were similar: 0.139 and 0.123/d for control and flavored diets, respectively. Data for both groups were
\end{abstract}

\footnotetext{
Received October 10, 2003.

Accepted January 23, 2004.

Corresponding author: M. A. Shah; e-mail: shahm@agr.gc.ca.

*Supported by the Braes Feed Ingredients, Inc., Wheeling, IL 60090.

$\dagger$ Present address: Lethbridge Research Centre, Agriculture and Agri-Food Canada, Lethbridge, Alberta, Canada T1J 4B1. To whom reprint request should be addressed.
}

separately analyzed using multiple regression with $3.5 \%$ fat-corrected milk as the dependent variable and BW and DMI as independent variables. More BW was mobilized per unit increase in 3.5\% fat-corrected milk in cows fed the control than in cows fed the flavored diet. Cows fed the control diet tended to be in more negative energy balance during early lactation than cows fed the flavored diet. It was concluded that feeding flavor improved energy balance of cows in early lactation and may reduce the risk of health or reproductive problems.

(Key words: transition period, flavor, dairy cow)

Abbreviation key: EB = energy balance.

\section{INTRODUCTION}

The transition period of a cow is generally defined as 3 wk prepartum to 4 wk postpartum (Grummer, 1995). This period is considered the most traumatic time of the annual cycle of the dairy cow (Keady et al., 2001) because metabolic disorders and health problems are very common during this time (Curtis et al., 1985). Physiologically and nutritionally, it is a stressful period, particularly as feed intake is reduced (Weiss, 1991; Murphy, 1999) and nutrient demand for the support of fetal growth in late pregnancy and milk production in early lactation is increased (NRC, 1989). In high-producing cows, DMI does not provide adequate nutrients to meet requirements. Weiss (1991) reported that DMI during the first week of lactation was 33\% less than peak DMI observed in wk 8 of lactation. High-producing cows, then, must mobilize energy and protein from limited body stores to support milk production. A critical interrelationship among energy demand, energy intake, and energy balance (EB) is thereby established (Bauman and Elliot, 1983).

Inadequate intake of nutrients during the transition period not only adversely affects milk production but also reduces reproductive efficiency (Reese et al., 1982; Nelssen et al., 1985). Increasing energy intake during the transition period might have positive effects on the health, milk production, and reproduction of high-producing dairy cows (Curtis et al., 1985; Grummer, 1995). 
Table 1. Nutrient composition of the pre- and postpartum control (C) and flavored (F) diets.

\begin{tabular}{lccccc}
\hline & \multicolumn{2}{c}{ Prepartum } & & \multicolumn{2}{c}{ Postpartum } \\
\cline { 2 - 3 } \cline { 6 - 7 } Item & $\mathrm{C}$ & $\mathrm{F}$ & & $\mathrm{C}$ & $\mathrm{F}$ \\
\hline $\mathrm{DM}, \%$ & 48.8 & 49.4 & & 58.4 & 60.6 \\
CP, \% of DM & 13.1 & 13.3 & & 17.9 & 17.6 \\
ADF, \% of DM & 32.0 & 32.9 & & 31.4 & 27.5 \\
NDF, \% of DM & 44.5 & 43.7 & & 38.9 & 40.3 \\
NEL, Mcal/kg of DM & 1.54 & 1.54 & & 1.57 & 1.57 \\
Ca, \% of DM & 1.12 & 1.07 & & 0.87 & 0.73 \\
P, \% of DM & 0.41 & 0.39 & & 0.54 & 0.46 \\
Mg, \% of DM & 0.26 & 0.26 & & 0.29 & 0.28 \\
K, \% of DM & 1.62 & 1.70 & & 1.87 & 1.54 \\
Na, \% of DM & 0.130 & 0.067 & & 0.423 & 0.377 \\
Fe, ppm in DM & 427 & 395 & & 415 & 328 \\
Zn, ppm in DM & 84 & 65 & & 96 & 87 \\
Cu, ppm in DM & 22 & 14 & & 21 & 15 \\
Mn, ppm in DM & 86 & 55 & & 85 & 92 \\
Mo, ppm in DM & $<1$ & $<1$ & & 1.5 & $<1$ \\
S, \% of DM & 0.30 & 0.25 & & 0.24 & 0.22 \\
\hline
\end{tabular}

Options explored to meet these challenges have included fat supplementation and various palatability factors, including feed flavors. Among the latter, the potential of feed flavors to enhance the feed consumption of dairy cows has been studied (Klopfer et al., 1981; Nombekela et al., 1994; Nombekela and Murphy, 1995; Murphy et al., 1997). Most previous flavor experiments with lactating dairy cows have involved periods of $<3$ wk (NRC, 1989) or have focused on postpartum effects (Nombekela and Murphy, 1995; Murphy et al., 1997). Feed flavor effects do not appear to have been studied throughout the transition period of the dairy cows; therefore, our objective was to evaluate the effects of a liquid feed flavor (Pos-Arome; Braes Feed Ingredients, Inc., Wheeling, IL) on dairy cows in the transition period.

\section{MATERIALS AND METHODS}

\section{Cows and Diets}

Twenty-four cows were divided into 2 groups (12 cows per group) and were assigned alternately, based on expected calving date, to either a control or a flavored diet according to a protocol (\#99321) approved by the University of Illinois Laboratory Animal Care Advisory Committee. A liquid flavor (Pos-Arome) was sprayed on the TMR at a rate of $0.52 \mathrm{~mL} / \mathrm{kg}$ of the feed as the diet was being mixed. An equivalent amount of water was added to the control diet. All cows were offered a dry cow diet 3 wk prepartum and, after calving, a diet for lactating cows through 6 wk postpartum (Table 1). The TMR was $33 \%$ corn silage, $17 \%$ coarsely chopped alfalfa hay, and $50 \%$ concentrate mix (ground shelled corn and soybean meal) on a DM basis. In addition to
Table 2. Least squares means for DMI, milk production, milk composition, and BW characteristics for cows fed the control (C) or flavored (F) diet; $P>0.05$ for all variables.

\begin{tabular}{|c|c|c|c|c|}
\hline \multirow[b]{2}{*}{ Item } & \multicolumn{4}{|c|}{ Treatment } \\
\hline & $\mathrm{C}$ & SEM & $\mathrm{F}$ & SEM \\
\hline \multicolumn{5}{|l|}{ DMI } \\
\hline Overall, kg/d & 15.8 & 0.2 & 14.4 & 0.2 \\
\hline Prepartum, kg/d & 13.3 & 0.2 & 11.7 & 0.2 \\
\hline \multicolumn{5}{|l|}{ Postpartum } \\
\hline $\mathrm{kg} / \mathrm{d}$ & 16.9 & 0.2 & 15.8 & 0.2 \\
\hline$\%$ of BW & 2.70 & 0.04 & 2.45 & 0.04 \\
\hline$\%$ of $\mathrm{BW}^{0.75}$ & 13.5 & 0.18 & 12.3 & 0.18 \\
\hline Milk yield, kg/d & 38.0 & 0.4 & 35.4 & 0.4 \\
\hline $3.5 \% \mathrm{FCM}, \mathrm{kg} / \mathrm{d}$ & 39.3 & 0.5 & 37.3 & 0.5 \\
\hline \multicolumn{5}{|l|}{ Milk protein } \\
\hline$\%$ & 3.12 & 0.02 & 3.11 & 0.02 \\
\hline $\mathrm{g} / \mathrm{d}$ & 115.6 & 1.3 & 107.3 & 1.3 \\
\hline \multicolumn{5}{|l|}{ Milk fat } \\
\hline$\%$ & 3.68 & 0.07 & 3.74 & 0.05 \\
\hline$g / d$ & 137.5 & 1.9 & 130.5 & 1.8 \\
\hline \multicolumn{5}{|l|}{ Milk SNF } \\
\hline$\%$ & 8.37 & 0.03 & 8.16 & 0.03 \\
\hline $\mathrm{kg} / \mathrm{d}$ & 1.42 & 0.02 & 1.28 & 0.02 \\
\hline Milk SCC, $\times 1000 / \mathrm{mL}$ & 204 & 98 & 460 & 72 \\
\hline \multicolumn{5}{|l|}{$\mathrm{BW}, \mathrm{kg}$} \\
\hline Prepartum & 748 & 18 & 737 & 14 \\
\hline Postpartum & 631 & 3.5 & 652 & 3.4 \\
\hline $\mathrm{BW}^{0.75}, \mathrm{~kg}^{0.75}$ & 125.9 & 0.5 & 128.8 & 0.5 \\
\hline 3.5\% FCM:DMI & 2.34 & 0.06 & 2.41 & 0.05 \\
\hline \multicolumn{5}{|c|}{ Energy balance, ${ }^{1} \mathrm{Mcal} / \mathrm{d}$} \\
\hline Prepartum & 4.7 & 0.8 & 0.9 & 0.5 \\
\hline Postpartum & -9.7 & 0.6 & -9.7 & 0.5 \\
\hline
\end{tabular}

${ }^{1} \mathrm{NE}_{\mathrm{L}}$ intake - net energy of maintenance - net energy of milk (NRC, 1989).

the TMR and treatment, cows received $2.3 \mathrm{~kg} / \mathrm{d}$ of alfalfa hay during wk 1 of lactation. Feed was offered to achieve $10 \%$ orts on an as-fed basis at 1100 and 1630 h. Orts were measured daily before the a.m. feeding and scored visually for DM content. The orts scores (integers from 1 to 4 ) were related to actual DM content by drying all ort samples at $55^{\circ} \mathrm{C}$ biweekly. Weekly feed samples were stored at $-4^{\circ} \mathrm{C}$ until the end of the experiment; monthly samples of ingredients and the TMR were composited and pooled for analysis (Dairy One Forage Laboratory, Ithaca, NY).

Cows were housed in tie stalls indoors except for a daily 3-h exercise period in a dry lot outdoors with only water available. Water was available indoors via individual cups for ad libitum consumption.

\section{Milk Yield and BW Measurements}

The BW was determined at the start of the trial and weekly during the experimental period. Milk production was measured at 0600 and $1500 \mathrm{~h}$ daily. Samples from consecutive p.m. and a.m. milkings were composted biweekly based on production and analyzed for fat and protein by midinfrared method (Dairy Lab Ser- 
Table 3. Parameter estimates ( $(\mathrm{SEEM})$ for the exponential model ${ }^{1}$ of DMI.

\begin{tabular}{|c|c|c|c|c|c|c|c|c|}
\hline \multirow[b]{2}{*}{ Diet } & \multicolumn{2}{|c|}{$\begin{array}{l}\text { Asymptotic } \\
\text { intake (a) }\end{array}$} & \multicolumn{2}{|c|}{$\begin{array}{l}\text { Potential for } \\
\text { increase (b) }\end{array}$} & \multicolumn{2}{|c|}{$\begin{array}{c}\text { Rate of } \\
\text { increase (c) }\end{array}$} & \multicolumn{2}{|c|}{$\begin{array}{l}\text { Proportion of } \\
\text { variance } \\
\text { explained }\left(R^{2}\right)\end{array}$} \\
\hline & $\mathrm{kg}$ & $\mathrm{SE}$ & $\mathrm{kg}$ & $\mathrm{SE}$ & $\mathrm{kg}$ & $\mathrm{SE}$ & Mean & $\mathrm{SE}$ \\
\hline Control & 20.31 & 0.8 & 13.32 & 1.5 & 0.139 & 0.02 & 0.70 & 0.04 \\
\hline Flavored & 18.73 & 0.8 & 13.94 & 1.4 & 0.123 & 0.02 & 0.72 & 0.04 \\
\hline Overall & 19.52 & 0.8 & 13.63 & 1.4 & 0.131 & 0.02 & 0.71 & 0.04 \\
\hline
\end{tabular}

${ }^{1} \mathrm{DMI}=\mathrm{a}-\mathrm{be}^{\mathrm{cct}}$, where $\mathrm{t}=\mathrm{DIM}$.

vices, Dubuque, IA) and SNF according to the method of Golding (1959). Production of 3.5\% FCM was determined as described by Tyrrell and Reid (1965).

\section{Statistical Analyses}

Data on daily DMI and milk yield were reduced to weekly means for each cow. Weekly data for DMI, BW, milk yield, and milk composition were analyzed using repeated measures analysis in SAS (1988). The model was: $\mathrm{Y}_{\mathrm{ijk}}=\mu+\mathrm{T}_{\mathrm{i}}+\mathrm{C}_{\mathrm{j}(\mathrm{i})}+\mathrm{W}_{\mathrm{k}}+(\mathrm{TW})_{\mathrm{ik}}+\varepsilon_{\mathrm{ijk}}$, where $\mathrm{Y}_{\mathrm{ijk}}=$ the dependent variable in treatment $i$ for cow $j$ within treatment $\mathrm{i}$ in week $\mathrm{k} ; \mu=$ common mean; $\mathrm{T}_{\mathrm{i}}=$ effect of treatment $\mathrm{i}(\mathrm{i}=1,2) ; \mathrm{C}_{\mathrm{j}(\mathrm{i})}=$ effect of cow $\mathrm{j}(\mathrm{j}=1$ to $12) ; \mathrm{W}_{\mathrm{k}}=$ effect of week $\mathrm{k}$ ( $\mathrm{k}=1$ to 3 for prepartum period and 1 to 6 for postpartum period); (TW $)_{\mathrm{ik}}=$ interactions of treatment $\mathrm{i}$ and week $\mathrm{k}$; and $\varepsilon_{\mathrm{ijk}}=$ random residual error. Dry matter intake and BW data were also analyzed for the prepartum period. Energy balance was calculated from DMI, BW, milk yield, and milk composition data (NRC, 1989). Repeated measures in the general linear model procedure in SAS (1988) were used to analyze EB data for the pre- and postpartum periods. Statistical significance was declared at $P<0.05$ unless otherwise indicated. The effect of treatments

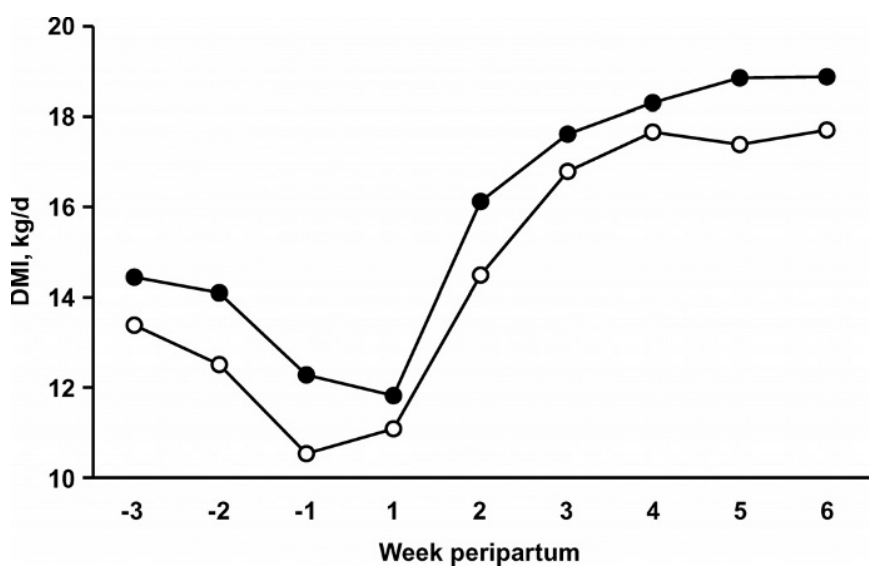

Figure 1. Least square mean DMI by week of lactation for cows fed the control $(\bullet)$ or flavored $(O)$ diets $(\mathrm{SE}=0.7 ; \mathrm{n}=12)$. was tested by using cows within treatment as the error term.

Milk energy output during early lactation is a function of DMI and BW loss; therefore, data for both groups were separately analyzed by multiple regression with $3.5 \% \mathrm{FCM}$ as the dependent variable and BW and DMI as the independent variables. This approach can be used to examine and predict the efficiency of milk production during early lactation.

Daily DMI for individual cows were also fitted to the model for postpartum DMI (Shah et al., 1998). All parameters of the models for both groups were compared using a two-sample t-test in SAS (1988).

\section{RESULTS AND DISCUSSION}

Nutrient compositions of the prepartum and postpartum experimental diets are presented in Table 1 . The diets were formulated to provide similar contents of $\mathrm{CP}, \mathrm{NE}_{\mathrm{L}}, \mathrm{ADF}, \mathrm{NDF}$, ether extract, $\mathrm{Ca}, \mathrm{P}, \mathrm{Mg}, \mathrm{K}$, and trace elements. The estimated $\mathrm{NE}_{\mathrm{L}}$ was $6 \%$ below the NRC (1989) recommended $1.67 \mathrm{Mcal} / \mathrm{kg}$ of DM for early lactation Holstein cows. Prepartum and postpartum $\mathrm{NE}_{\mathrm{L}}$ values were close to those used in previous studies

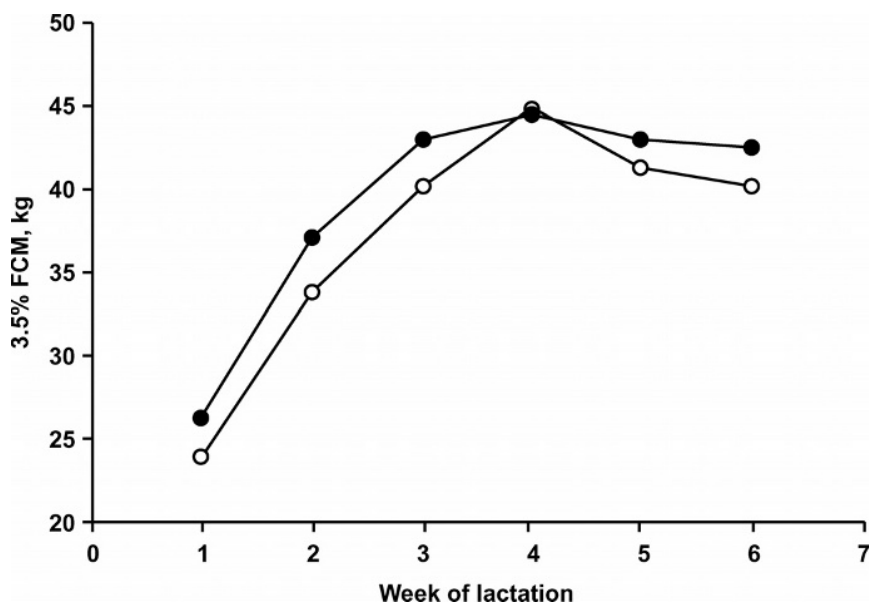

Figure 2. Least square mean 3.5\% FCM by week of lactation for cows fed the control $(\bullet)$ or flavored $(\bigcirc)$ diets $(\mathrm{SE}=1.3 ; \mathrm{n}=12)$. 


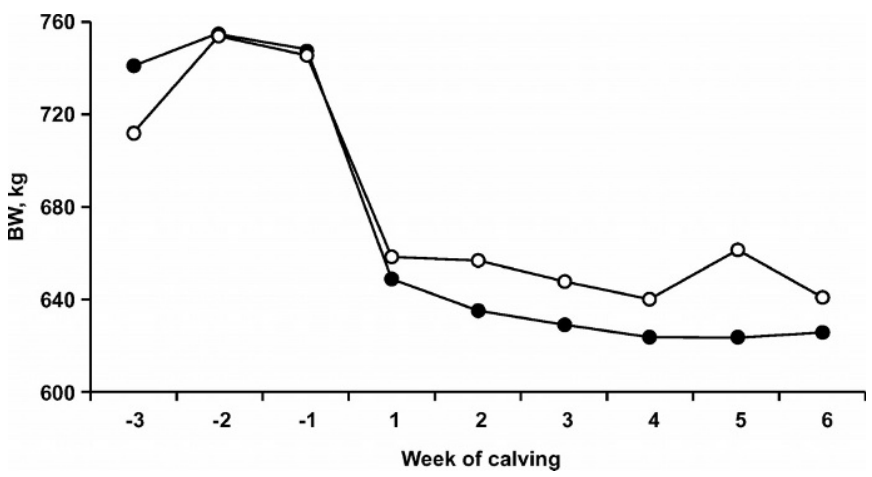

Figure 3. Least square mean BW by week of lactation for cows fed the control $(\bullet)$ or flavored $(\bigcirc)$ diets $(\mathrm{SE}=16 ; \mathrm{n}=12)$.

by Nombekela et al. (1994) and Murphy et al. (1997), respectively. Alfalfa hay was supplemented for $1 \mathrm{wk}$ after calving to augment effective fiber intake.

Least squares means for DMI, milk yield and composition, and BW measures are given in Table 2. There was no interaction of treatment with time for any of the variables. Overall, prepartum and postpartum mean DMI were not affected by flavor supplementation (Table 2; Figure 1). These findings were in agreement with the results of others (Murphy et al., 1997; Nombekela and Murphy, 1995).

Nombekela et al. (1994) reported dairy cows preferred a sweetened diet in early lactation; however, that experiment involved short-term sequential elimination trials with multiple diets. In this study, single diets were fed for $9 \mathrm{wk}$; therefore, postpartum preference for a flavored diet might have been reduced by repeated exposure for a longer time (Early and Provenza, 1998).

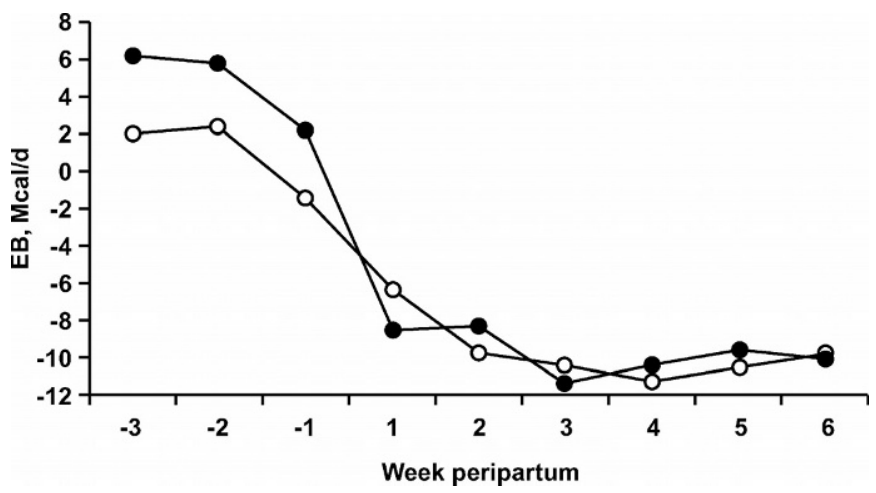

Figure 4. Least square mean of energy balance (EB) by week of lactation for cows fed the control $(\bullet)$ or flavored $(O)$ diets $(\mathrm{SE}=0.5$; $\mathrm{n}=12$ ).

Preference for sucrose-supplemented diets was observed in a variety of species when diets were offered in multiple-choice arrangements (Aumaitre, 1978; Treit et al., 1983; Naim et al., 1985); however, during early lactation, the DMI of dairy cows was not significantly affected when a sucrose-supplemented diet was offered alone in a 12-wk trial (Nombekela and Murphy, 1995). Lower intake following a transitory increase in intake (Dow, 1959) may result from "flavor fatigue" in singlechoice designs (Nombekela and Murphy, 1995).

Although there was no statistically significant difference in DMI between groups of cows (Table 2), a greater increase (35\% vs. $27 \%$ from prepartum to postpartum) was observed for cows fed flavored diets compared with control diets (Table 2; Figure 1). Dairy cows with high genetic potential for milk yield can increase DMI by as much as $150 \%$ between calving and wk 4 of lactation

Table 4. Pearson correlation coefficients of various animal, dietary, and production measures. ${ }^{1}$

\begin{tabular}{lllllllllllrrrrr}
\hline Variable $^{2}$ & 1 & 2 & 3 & 4 & 5 & 6 & 7 & 8 & 9 & 10 & 11 & 12 & 13 & 14 & 15 \\
\hline 1 & 1.00 & 1.00 & -0.05 & 0.08 & 0.08 & 0.04 & 0.03 & 0.15 & 0.07 & -0.11 & 0.13 & -0.43 & -0.02 & -0.34 & 0.16 \\
2 & $* * *$ & 1.00 & -0.04 & 0.09 & 0.09 & 0.04 & 0.04 & 0.15 & 0.07 & -0.12 & 0.13 & -0.43 & -0.01 & -0.34 & 0.16 \\
3 & $\mathrm{NS}$ & $\mathrm{NS}$ & 1.00 & 0.58 & 0.58 & 0.68 & 0.69 & -0.21 & -0.30 & -0.06 & -0.22 & 0.92 & 0.96 & 0.95 & -0.34 \\
4 & $\mathrm{NS}$ & $\mathrm{NS}$ & $* * *$ & 1.00 & 1.00 & 0.88 & 0.91 & 0.19 & -0.49 & -0.05 & -0.39 & 0.50 & 0.49 & 0.53 & 0.53 \\
5 & $\mathrm{NS}$ & $\mathrm{NS}$ & $* * *$ & $* * *$ & 1.00 & 0.88 & 0.91 & 0.19 & -0.49 & -0.05 & -0.39 & 0.50 & 0.49 & 0.53 & 0.53 \\
6 & $\mathrm{NS}$ & $\mathrm{NS}$ & $* * *$ & $* * *$ & $* * *$ & 1.00 & 0.95 & -0.19 & -0.35 & -0.07 & -0.35 & 0.62 & 0.60 & 0.65 & 0.33 \\
7 & $\mathrm{NS}$ & $\mathrm{NS}$ & $* * *$ & $* * *$ & $* * *$ & $* * *$ & 1.00 & -0.21 & -0.62 & -0.08 & -0.47 & 0.63 & 0.57 & 0.66 & 0.35 \\
8 & $\mathrm{NS}$ & $\mathrm{NS}$ & $*$ & $*$ & $*$ & $*$ & $*$ & 1.00 & 0.21 & 0.07 & 0.19 & -0.29 & -0.15 & -0.28 & 0.35 \\
9 & $\mathrm{NS}$ & $\mathrm{NS}$ & $* * *$ & $* * *$ & $* * *$ & $* * *$ & $* * *$ & $*$ & 1.00 & 0.05 & 0.68 & -0.32 & -0.15 & -0.32 & -0.23 \\
10 & $\mathrm{NS}$ & $\mathrm{NS}$ & $\mathrm{NS}$ & $\mathrm{NS}$ & $\mathrm{NS}$ & $\mathrm{NS}$ & $\mathrm{NS}$ & $\mathrm{NS}$ & $\mathrm{NS}$ & 1.00 & -0.21 & -0.01 & -0.11 & -0.02 & 0.01 \\
11 & $\mathrm{NS}$ & $\mathrm{NS}$ & $* * *$ & $* * *$ & $* * *$ & $* * *$ & $* * *$ & $*$ & $* * *$ & $*$ & 1.00 & -0.25 & 0.05 & -0.25 & -0.25 \\
12 & $* * *$ & $* * *$ & $* * *$ & $* * *$ & $* * *$ & $* * *$ & $* * *$ & $* *$ & $* * *$ & $\mathrm{NS}$ & $* *$ & 1.00 & 0.87 & 1.00 & -0.35 \\
13 & $\mathrm{NS}$ & $\mathrm{NS}$ & $* * *$ & $* * *$ & $* * *$ & $* * *$ & $* * *$ & $\mathrm{NS}$ & $\mathrm{NS}$ & $\mathrm{NS}$ & $\mathrm{NS}$ & $* * *$ & 1.00 & 0.91 & -0.40 \\
14 & $* * *$ & $* * *$ & $* * *$ & $* * *$ & $* * *$ & $* * *$ & $* * *$ & $* *$ & $* * *$ & $\mathrm{NS}$ & $* *$ & $* * *$ & $* * *$ & 1.00 & -0.35 \\
15 & $\mathrm{NS}$ & $\mathrm{NS}$ & $* * *$ & $* * *$ & $* * *$ & $* * *$ & $* * *$ & $* * *$ & $*$ & $\mathrm{NS}$ & $* *$ & $* * *$ & $* * *$ & $* * *$ & 1.00 \\
\hline
\end{tabular}

${ }^{1}$ Above the diagonal are the Pearson correlation coefficients, and below the diagonal are the levels of significance, where $* P<0.05$, $* * P$ $<0.01$, and $* * * P<0.001$.

${ }^{2}$ Variables: 1 = BW, $2=$ BW $^{0.75}, 3=\mathrm{DMI}, 4=3.5 \% \mathrm{FCM}, 5=$ milk fat yield, $6=$ milk protein yield, $7=$ milk yield, $8=$ milk fat percentage, $9=$ milk protein percentage, $10=\mathrm{SCC}, 11=$ milk SNF percentage, $12=\mathrm{DMI}$ as a percentage of BW, $13=$ milk SNF yield, $14=\mathrm{DMI}$ as a percentage of $\mathrm{BW}^{0.75}$, and $15=3.5 \% \mathrm{FCM} / \mathrm{DMI}$. 


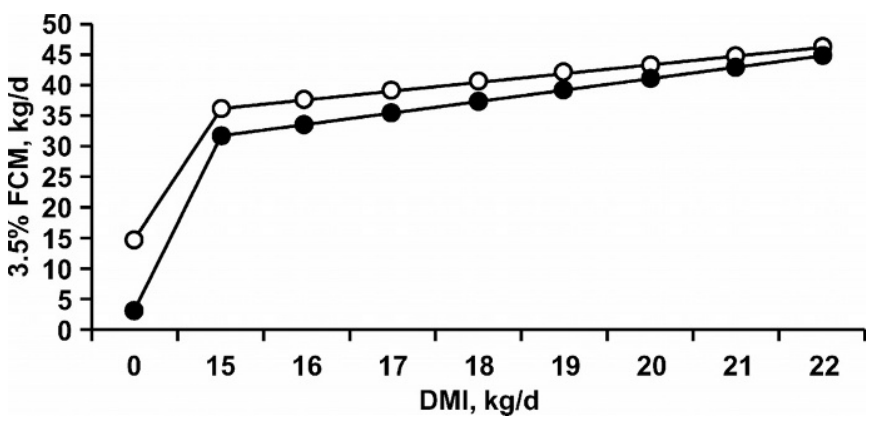

Figure 5. Predicted 3.5\% FCM yield at various DMI (keeping BW constant) for cows fed the control $(\bullet)$ or flavored $(\bigcirc)$ diets. These estimates are based on regression analysis, where 3.5\% FCM was a dependent variable and DMI and BW were independent variables.

(Soder and Holden, 1999). To facilitate this increase, cows must maintain sufficient DMI immediately prior to and after calving (Bertics et al., 1992). In this study, we observed a $73 \%$ increase in DMI from wk 1 prepartum to wk 4 postpartum for cows fed flavored diets as compared with the 50\% increase for the control group (Figure 1); however, there was no effect of flavor on postpartum rate of increase in DMI (Table 3). When exponential model (Shah et al., 1998) was fitted to postpartum daily DMI data for each cow, there was no difference between cows fed flavored and control diets in their asymptotic DMI, potential increase in DMI or fractional rate of increase in DMI $(P>0.10$; Table 3$)$. The exponential model explained 72 and $70 \%$ of the variation in DMI for cows fed flavored and control diets, respectively (Table 3 ).

Milk yield did not differ between cows fed the flavored diet and the control diet (Table 2). The response in milk yield was closely correlated with DMI $(P<0.01$; Table 4 , Figure 2). These results are in agreement with the findings of others (Nombekela and Murphy, 1995; Murphy et al., 1997). There was no difference in 3.5\% FCM yield between cows fed the flavored or the control diet (Table 2); however, numerically, control cows yielded $5.4 \%$ more $3.5 \%$ FCM. This higher yield was not the result of a higher efficiency of utilization of DMI but a

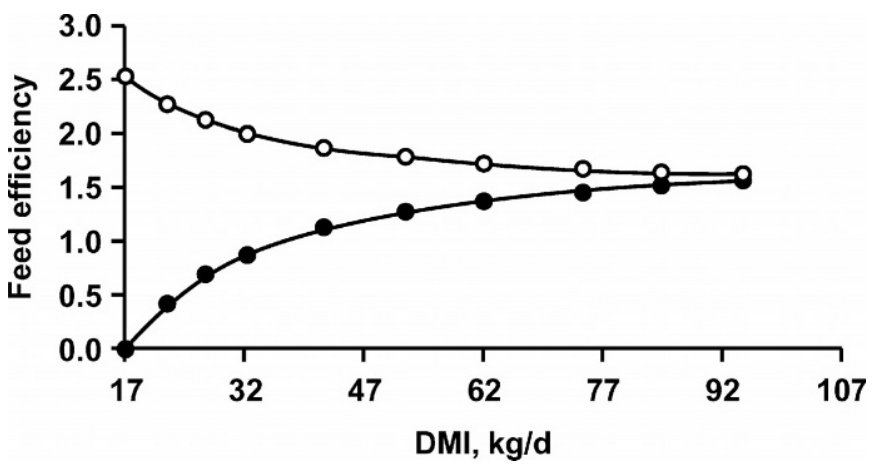

Figure 6. Projected feed efficiency for cows fed the control $(\bullet)$ or flavored $(\bigcirc)$ diets. These findings are based on regression analysis, where $3.5 \%$ FCM was a dependent variable and DMI and BW were independent variables.

greater loss of BW in cows fed the control diet (Table 2; Figure 3). Because the efficiency of milk production during early lactation was similar for both groups, no difference in EB was observed (Table 2; Figure 4).

During early lactation, milk yield increases rapidly, whereas DMI has a slower rate of increase (NRC, 1989). Thus, in high-yielding cows, DMI does not provide adequate nutrients for increased demand. The high-producing cow, then, must mobilize energy and protein from limited body stores to support milk production. Milk production during early lactation, when cows are in negative $\mathrm{EB}$, is not just a function of DMI but rather is related to BW loss and DMI. Therefore, milk production efficiency can be measured more appropriately if both BW loss and DMI are accounted for. Using this approach to monitor efficiency, it was predicted that cows fed the flavored diet yielded more 3.5\% FCM as DMI increased up to $22 \mathrm{~kg} / \mathrm{d}$, keeping BW constant (Figure 5). It was also predicted that cows fed the flavored diet lost less BW as 3.5\% FCM yield increased when compared with cows fed the control diet (Table 5). If no BW loss associated with 3.5\% FCM yield for both groups of cows was assumed, then the predicted feed efficiency was consistently higher for cows fed the flavored diet in the normal range of DMI (Figure 6).

Table 5. Summary of regression analyses. ${ }^{1}$

\begin{tabular}{|c|c|c|c|c|c|c|}
\hline \multirow[b]{2}{*}{ Variable } & \multicolumn{3}{|c|}{ Control diet } & \multicolumn{3}{|c|}{ Flavored diet } \\
\hline & $\begin{array}{l}\text { Parameter } \\
\text { estimate }\end{array}$ & $\mathrm{SE}$ & $P^{2}$ & $\begin{array}{l}\text { Parameter } \\
\text { estimate }\end{array}$ & $\mathrm{SE}$ & $P^{2}$ \\
\hline Intercept & -32.96 & 11.04 & $<0.005$ & 19.22 & 10.01 & 0.06 \\
\hline BW, kg & 0.063 & 0.016 & $<0.001$ & -0.007 & 0.014 & 0.62 \\
\hline DMI, kg & 1.900 & 0.244 & $<0.001$ & 1.418 & 0.262 & $<0.001$ \\
\hline $\mathrm{R}^{2}$ & 0.53 & & & 0.30 & & \\
\hline
\end{tabular}

${ }^{1}$ The dependent variable was $3.5 \%$ FCM.

${ }^{2}$ Probability of significance. 
One unit loss of BCS by a $650-\mathrm{kg}$ Holstein cow provides $21.3 \%$ (399 Mcal) less $\mathrm{NE}_{\mathrm{L}}$ compared with the $\mathrm{NE}_{\mathrm{L}}$ required to gain one unit of body condition score (484 Mcal; NRC, 2001). Therefore, the overall economic efficiency of production will be higher for cows fed the flavored diet than for cows fed the control diet. The mechanism by which liquid flavor reduced BW loss while maintaining DMI and milk yield requires further investigation.

\section{CONCLUSIONS}

Overall, feed consumption of dairy cows in this trial was not enhanced by liquid flavor supplementation at the rate of $0.52 \mathrm{~mL} / \mathrm{kg}$ of the feed; however, it was observed that loss of body condition 1 wk prepartum and $2 \mathrm{wk}$ postpartum was reduced by liquid flavor. The extent of flavor effect on DMI may be determined by a variety of factors including the basal diet, amount of flavor supplementation, and diet presentation. Therefore, further studies are required to investigate flavormediated effects on the performance of dairy cows.

\section{REFERENCES}

Aumaitre, A. 1978. Palatability of piglet feeds: trial methods and practical results. Pages $86-95$ in 1st Int. Symp. Palatability and Flavor Use in Animal Feeds, Zurich, Switzerland. Verlag Paul Parey, Hamburg, Germany.

Bauman, D. E., and J. M. Elliot. 1983. Control of nutrient partitioning in lactating ruminants. Pages 437-468 in Biochemistry of Lactation. T. B. Mepham, ed. Elsevier Sci. Publ., B. V., Amsterdam, The Netherlands.

Bertics, S. J., R. R. Grummer, C. Cadorniga-Valino, and E. E. Stoddard. 1992. Effect of prepartum dry matter intake on liver triglyceride concentration and early lactation. J. Dairy Sci. 75:19141922.

Curtis, C. R., H. N. Erb, C. J. Sniffen, R. D. Smith, and D. S. Kronfeld. 1985. Path analysis of dry period nutrition, postpartum metabolic and reproductive disorders, and mastitis in Holstein cows. J. Dairy Sci. 68:2347-2360.

Dow, J. K. D. 1959. The sense of taste in the domesticated animals. Vet. Rec. 71:1071-1079.

Early, D. M., and F. D. Provenza. 1998. Food flavor and nutritional characteristics alter dynamic of food preference in lambs. J. Anim. Sci. 76:728-734.

Golding, N. S. 1959. A solids-not-fat test for milk using density plastic beads as hydrometers. J. Dairy Sci. 42(Suppl. 1):899. (Abstr.)
Grummer, R. R. 1995. Impact of changes in organic nutrient metabolism on feeding the transition dairy cow. J. Anim Sci. 73:28202833.

Keady, T. W. J., C. S. Mayne, D. A. Fitzpatrick, and M. A. McCoy. 2001. Effect of concentrate feed level in late gestation on subsequent milk yield, milk composition and fertility of dairy cows. J. Dairy Sci. 84:1468-1479.

Klopfer, F. D., R. Kilgour, and L. R. Mathews. 1981. Paired comparison analysis of palatability of twenty foods to dairy cows. Proc. N.Z. Soc. Anim. Prod. 41:242-247.

Murphy, J. J. 1999. Effect of dry period protein feeding on postpartum milk production and composition. Livest. Prod. Sci. $57: 169-179$

Murphy, M. R., A. W. P. Geijsel, E. C. Hall, and R. D. Shanks. 1997. Dietary variety via sweetening and voluntary feed intake of lactating dairy cows. J. Dairy Sci. 80:894-897.

Naim, M., J. G. Brand, M. R. Kare, and R. G. Carpenter. 1985. Energy intake, weight gain and fat deposition in rats fed flavored, nutritionally controlled diets in a multichoice ("cafeteria") design. J. Nutr. 115:1447-1458.

National Research Council. 1989. Nutrient Requirements of Dairy Cattle. 6th rev. ed. Natl. Acad. Sci., Washington, DC.

National Research Council. 2001. Nutrient Requirements of Dairy Cattle. 7th rev. ed. Natl. Acad. Sci., Washington, DC.

Nelssen, J. L., A. J. Lewis, E. R. Peo, Jr., and J. D. Crenshaw. 1985. Effect of dietary energy intake during lactation on performance of primiparous sows and their litters. J. Anim. Sci. 61:1164-1171.

Nombekela, S. W., and M. R. Murphy. 1995. Sucrose supplementation and feed intake of dairy cows in early lactation. J. Dairy Sci. 78:880-885.

Nombekela, S. W., M. R. Murphy, H. W. Gonyou, and J. I. Marden. 1994. Dietary preferences in early lactation cows as affected by primary tastes and some common feed flavors. J. Dairy Sci. 77:2393-2399.

Reese, D. E., B. D. Moser, E. R. Peo, Jr., A. J. Lewis, D. R. Zimmerman, J. E. Kinder, and W. W. Stroup. 1982. Influence of energy intake during lactation on the interval from weaning to first estrus in sows. J. Anim. Sci. 55:590-598.

SAS/STAT ${ }^{\circledR}$ User's Guide: Statistics, Version 6.12 ed. 1988. SAS Inst., Inc., Cary, NC.

Shah, M. A., M. R. Murphy, R. N. Corley, III, C. Cain, V. M. Carson, N. L. Whitehouse, P. S. Erickson, and C. G. Schwab. 1998. Analysis of day-to-day variation in the feed intake of lactating dairy cows. J. Dairy Sci. 81(Suppl. 1):314. (Abstr.)

Soder, K. J., and L. A. Holden. 1999. Dry matter intake and milk yield and composition of cows fed yeast prepartum and postpartum. J. Dairy Sci. 82:605-610.

Treit, D., M. L. Spetch, and J. A. Deutsch. 1983. Variety in the flavor of food enhances eating in the rat: a controlled demonstration. Physiol. Behav. 30:207-211.

Tyrrell, H. F., and J. T. Reid. 1965. Prediction of the energy value of the cow's milk. J. Dairy Sci. 48:1215-1223.

Weiss, W. P. 1991. Estimating dry matter intake. Page 9 in Proc. Ohio Dairy Nutr. Conf., Wooster, OH. Ohio State Univ., Columbus. 